Olga V. Nechiporenko

Vsevolod V. Samsonov

Institute of Philosophy and the Law

Russian Academy of Science, Siberian Branch

Novosibirsk, Russia

olganechiporenko@yandex.ru

highbook@ya.ru
UDK: $316.334 .55: 316.422(470+571)$

Оригинални научни рад

Рад примљен: 10.9.2016.

\title{
RUSSIAN COUNTRYSIDE: STAGES OF CHANGE, ADAPTION TO REFORMS AND NEW GLOBAL CHALLENGES $^{1}$
}

Summary: This paper deals with the generalization of experience of the transformation of Russian countryside, with regard to interrelationship between the economic and social aspects of transformation, as well as with the analysis of the current situation in the development of rural areas. This is due to a specific effect of post-socialist heritage and global challenges of our time. Our research is based on the results of the sociological surveys of change in strategies of social adaptation of rural population in Russia. It was done by the authors with uniform research techniques in Siberia, Volga region, Altai from 1993 to 2014.

Keywords: differentiation, diversification, economic structures, globalization, polarization, rural development, rural society, social adaptation.

$$
* * *
$$

The countryside is traditionally considered as the most conservative segment of society in respect of it's susceptibility to new influences. Meanwhile, the Russian rural society on the boundary for centuries had been showing to attentive researchers surprising dynamics of the changes, mentioned both in economy and in sphere of social relations. The purpose of given paper is to analyze indicators of social and economic development of Russian countryside - to show that on its basis it is possible to allocate, at least, four stages in Russian rural development in the conditions of transformation (since the 1980s). The analysis of the maintenance of these stages of transformation allows us to allocate them and divide in two periods: if the first is spontaneous creativity of adaptive socio-economic forms

\footnotetext{
${ }^{1}$ This paper was financially supported by RFFI (project No 15-03-00605).
} 
(essentially opposing market-based restructuring of society), the essence of the second period, that lasts until today, is the extinction of passive-adaptive forms and expansion of clusters of the market, the dominance of economically-oriented economic structures.

The objective of this paper is to reveal the actual structural changes in the socio-economic and socio-political spheres of the rural society. Our research is based on studies of social processes in rural communities over the last 20 years (i.e. the period of formation of new economic structures and the population's adaptation to market reforms), consisting of the successive stages of complex monitoring of processes of social modernization of modern Russian countryside, done by a group of authors on the territory of Siberia, the Volga region, Altai, and also in Belarusian and Kazakh rural areas.

Being primarily focused on economic and institutional changes, we tried to cover in our research the whole range of changes: social behavior, daily practice, ethno-cultural aspects, changes in the rural way of life, political modernization of rural society (including issues of social partnership and local democracy). A comprehensive study of dynamics of change in rural communities include at least three sets of problems, containing more than 100 variables: the socio-economic bloc, covering the problems associated with the level of income of the rural population, property relations, the situation on labor market and forms of employment and the predominant economic activities; socio-demographic block; socio-structural block, comprising questions of social organization and social relationships of rural communities, the network community profile, the level of trust and social capital, norms that structure social interaction of individuals and groups.

Comparative analysis of local communities is based on an assessment of factors that differentiate the rural area of Russia, such as:

- Natural resources and conditions (agricultural development and settlement patterns);

- Economic and geographical position (a suburb and peripherals);

- Ethno-cultural factors (composition of the population, the history of local communities, human and social capital of the community).

These objective factors affecting the diversity of rural areas, determine the capabilities and limitations of its development.

Changes in the life of Russian countryside were surveyed in the course of complex research, with special emphasis on the combination of quantitative and qualitative methods of social research ("mixed method"): a massive survey, focus groups discussion, participant observation etc. 


\section{The first period of transformation of the Russian countryside: market reforms}

At the first stage, prior to the beginning of 1990s, the economy had functioned in the form of the collective farms which are based on the state or collectivefarm property. At the second stage (from 1991 to the middle of 1990s) the reforms had begun to reorient Russian countryside from plan-redistributive to market economy. The agrarian reforms were based on the ideas of "peasantry revival" and returning of the Russian village to the path interrupted by the Revolution. Rural workers lacked the sense of ownership of a land and other means of production, which was considered the major reason of low efficiency of agricultural production. It was supposed that transfer to private ownership of land and property of the former collective farms, will cause considerable positive changes in management of the agricultural enterprises and in economic indicators of development of villages. Reforms provided constructive transformations to agrarian sector of the countries of the former USSR and included: land reform, reorganization of collective farms and state farms, development of a private sector of agrarian economy with a view of increase of social activity and the economic initiative of agricultural population, development of capitalist small-scale economy (farming). It was supposed that the reforms would create multi-structured, economically effective agricultural production.

The policy of spontaneous market transformations has led to sharp decrease in quality and an agricultural population's standard of living, distribution of the official and latent unemployment, falling of manufacture, and degradation of a social infrastructure of villages. "This was reflected in the Law of the Land Fund (1991), which started a long and controversial process of land system change. The law established the right of members of agricultural cooperatives (SPK) to get into private property land holdings made by them in the course of co-operation of the peasants in the 1949-1962. This means the actual liquidation of more than four thousand agricultural production cooperatives, which accounted for $47 \%$ of agricultural land" (Bogoljubov, Brinchuk, Vedysheva, 2011: 240).

Changes in institutional and social spheres directly influenced the adaptation strategy of the population, predetermining their evolution observed for last twenty years. At the first stage of transformation the model of adaptation of rural population frequently tend to be of a passive-adaptive character. The strategy of survival of the modern Russian countryside represents the adaptation not only to the market, but also to social consequences of agrarian reform (unemployment, economic poverty). The passive strategy of adaptation in Russian countryside was showed in a naturalization phenomenon (reorientation of the population to self-maintenance with the basic vital products of a subsistence economy, self-employment in a 
personal farmstead). The economic potential of personal part-time farms (PPTF, or on Russian "lichnoe podsobnoe hozjajstvo" - literally "individual subsidiary household") tend to be the major adaptation resource of Russian countryside, the labor efforts spent for cultivation of production become prevailing in activity structure of villagers. In the conditions of decrease in a standard of living and delays of salaries, the economic contribution of "household" to the family budget essentially increases, and the "household employment" starts to compete in importance to formal employment. Complexities of an economic situation have cleared the way for the come back of the traditional survivals based on the Russian experience in days of wars and social shocks. For a considerable part of the population, activity expansion of "self-maintenance" with foodstuff and "self-service" of households, which is not the rational innovative adaptation to market economy, by perception of new standards and norms of behavior, characteristic for a market society, and flight from it, sometimes in pre-market ways, became natural result of adaptation to shock therapy. The Russian province tries to adapt to a new economic reality "having taken cover rough, but a reliable cover natural economy" (Vagin, 1997).

\section{Three types of adaptation of rural society in conditions of reforms}

The third stage (the middle 1990s) is characterized by the end of the first wave of institutional transformations and definitive registration of passive mechanisms of adaptation of rural society, with gradual increase of value and institutionalization of informal economics. Monitoring researches of social realities of processes of transformations of the rural local communities, conducted by the authors in 1997-2007 in Siberian region (Novosibirsk, Tyumen, the Kemerovo region, Republic Altai) have allowed to allocate three basic types of adaptation reactions of rural local communities to the changes of the global social environment: natural, informal, destructive.

The first type of adaptation, natural, based on strategy of social and economic re-naturalization, expressed in development of traditional practices of the life-support, was strong depended from the state transfers. Reorientation of all social life to reproduction of the naturalized family economy which serves, first of all, to the purposes of simple reproduction and provides the minimum of comprehensible standard of living - is the most typical passive-adaptive reaction. It is possible to characterize it as orientation to a survival and not to development.

In the rural areas far from the large city centers, prevalence of natural sector in 1990 had an overwhelming character. Such state of affairs is noted in agricultural areas of Altai, Mountain Shorii, remote areas of Novosibirsk and the Kemerovo region. The analysis of the data of sociological monitoring has shown that the rural 
natural economy is not an independent economic phenomenon, since it cannot exist without the presence of powerful redistributive stream, directed from «the big society» to the economy of rural communities. At least two thirds of all material means used by countrymen came out of the local community. Stability of a subsistence economy assumes support of hi-tech modern economy (for preparation of forages, fire wood, production processing etc.). Resource of such support used to be utilized in the reformed collective household of the Soviet era, whose resources are accessible to a network of households both on the basis of preferential using and in the form of direct assignment (informal help, direct plunders) that gives the chance to researchers to characterize the similar enterprises as the "mixed communal-economic formations" (Paciorkovskij, 2003) in which the overwhelming majority of countrymen got access to redistributive mechanism, appropriating pubic resources in various forms.

The second type of adaptation of rural communities to the conditions that have changed due to an agrarian reform we call informal. The informal type of adaptation is based on a wide circulation of mechanisms of informal economic practices of households. In Kosh-Agachsky area of Republic Altai we found that the growth of marketability of personal economy was at the expense of sale of production of animal industries to private buyers from other regions of Russia and Mongolia, and also active black-market relations round transit trade, which flow from China to Russia, passing through Mongolia. Similar processes were found in Karasuksky area of the Novosibirsk region, which specificity were caused by frontier position with Kazakhstan that stimulated development of shadow enterprise activity. In Mountain Shorii the black market of furs and other products of hunting have been intensively developed. In the Tyumen and Kemerovo areas many countrymen were included in the black-market schemes existing round the enterprisesmining (an oil and gas complex and coal-mining) (Marhinin, Udalova, 2002). The market growth of the rural economy in the late 1990s and early 2000s was based upon the informal economic practices and it had taken dominating positions in meat and milk manufacturing at the all-Russian scale.

The third type of adaptation - destruction is characterized by progress of disintegration of the social communications and the strengthened migration that, in the final stage, led to a decay of local community. The vast presence of the destructive type of adaptation of rural communities was shown when intense redistributive stream appeared insufficient (bankruptcy of a large-scale enterprise) and also when there were no external factors of adaptation (natural resources, local commodity markets) to allow a development of informal social and economic practices. 
Figure 1. Factors determining the type of adaptation practices

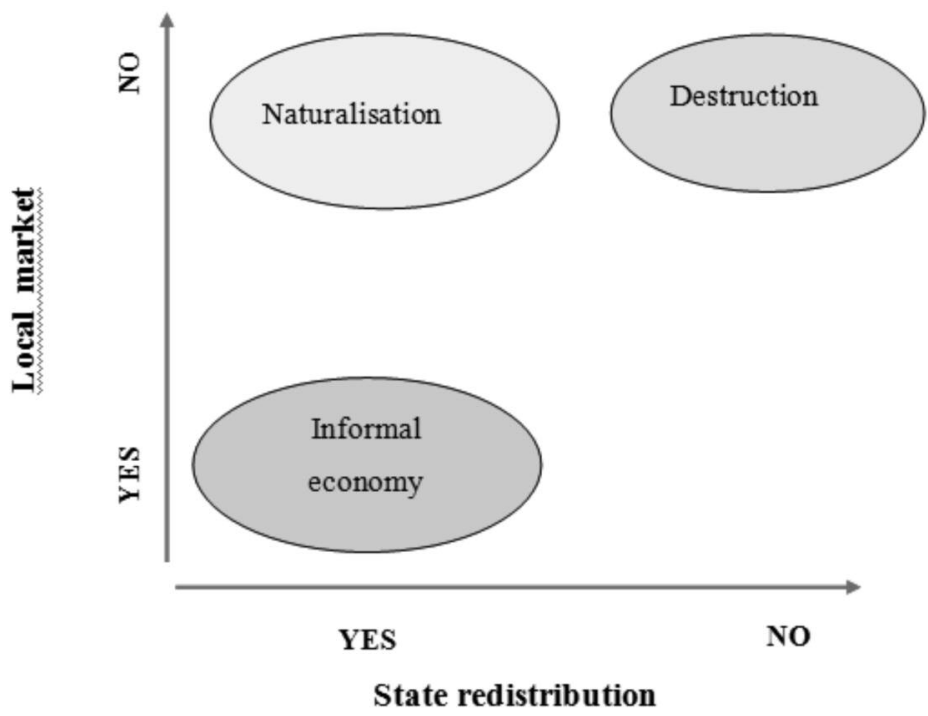

The study of the situation in various regions lead to the conclusion that the mentioned types of adaptation are not parallel and independent, but represent different aspects of a single process, have different flowing in different circumstances and under different conditions (Figure 1). There were regions with both distribution channels of agricultural products and access to redistributive structures of widespread informal economic practices. In the absence of a local market, population made a reorientation of the whole social life and the reproduction of a naturalized family farm. In the absence of markets, flow rate was insufficient redistributive and that caused the decay of rural communities.

\section{The present stage of transformation of Russian countryside: innovation trends}

In the newest, the fourth stage of development of modern Russian countryside (from the beginning of 2000s), the social and economic relations based on a private property of land influenced the evolution of the forms of mass social and economic behavior. Conditions of macroeconomic stabilization contributed to the appearance of a new wave of transformations. Those consists of gradual replacement of the socially-adaptable forms and structures that have generated in 1990s 
(economically inefficient) and entry of a "big business" (often city-based) into the rural economy.

In conditions of post-transformation stabilization, the role of crisis-adaptation forms decreased. According to the official statistics, since the year 2000 there has been gradual, but a steady decrease of the share of PPTF in the value structure of the national economy. The peak was reached in 2000, when PPTF made more than half of commodity meat (58 \%), and by 2013 the share PPTF in meat manufacture being gradually reduced, has decreased to $26,9 \%$ (returning to the pre-reform values). In the same years, the share of PPTF in manufacture of a commodity potato $(10 \%)$ has considerably decreased as well.

The data of the sociological researches done in the Novosibirsk region show even more considerable reduction of cattle-breeding specialization of PPTF - in overwhelming majority of the surveyed settlements there was a reduction of a livestock of public herd for two times and more. The data of inter-regional research (Novosibirsk and Saratov regions, 2010) confirms that the rural population shows the tendency of decrease in economic activity of PPTF.

The tendencies in decrease of a role of natural and small-scale form (PPTF) correlate with the general dynamics of orientations of the population in selfemployment sphere. The research done in the beginning of 2010s has shown that today the soil is necessary to Russians for habitation building, instead for the sake of reception of products (VCIOM, 2010) - the majority of Russians would like to have a plot of the soil for house building. Production of agricultural products for a family, which was dominate motive in the 1990s (56\%), today takes only 15 $\%$ of interviewees. The cited data convincingly testifies that in the Russian society at level of mass orientations, despite the social and economic difficulties in the last years (connected with consequences of world financial crisis), there is a refusal of passive household adaptation strategy.

The social and economic experts observed the increase of the value of incomes and salary in households and simultaneous decrease in incomes of sale of production of a part-time farm (Figure 2).

This tendency is connected with deep processes of transformation of the Russian rural society. First, due to degradation of industrial potential of unprofitable or remunerative collective farms ("kruphoz'es"), their social functions weaken. The majority of the former collective farms needed support from the state to survive, but the modern course of the state agrarian policy is directed on "improvement" of agricultural manufacturers - i.e., refusal of support to unprofitable enterprises.

Secondly, changes in Russian countryside appear due to the fact that the economy of survival loses its relevance for a certain period of development. The eco- 
Figure 2. Dynamic of structure of monetary incomes of rural households

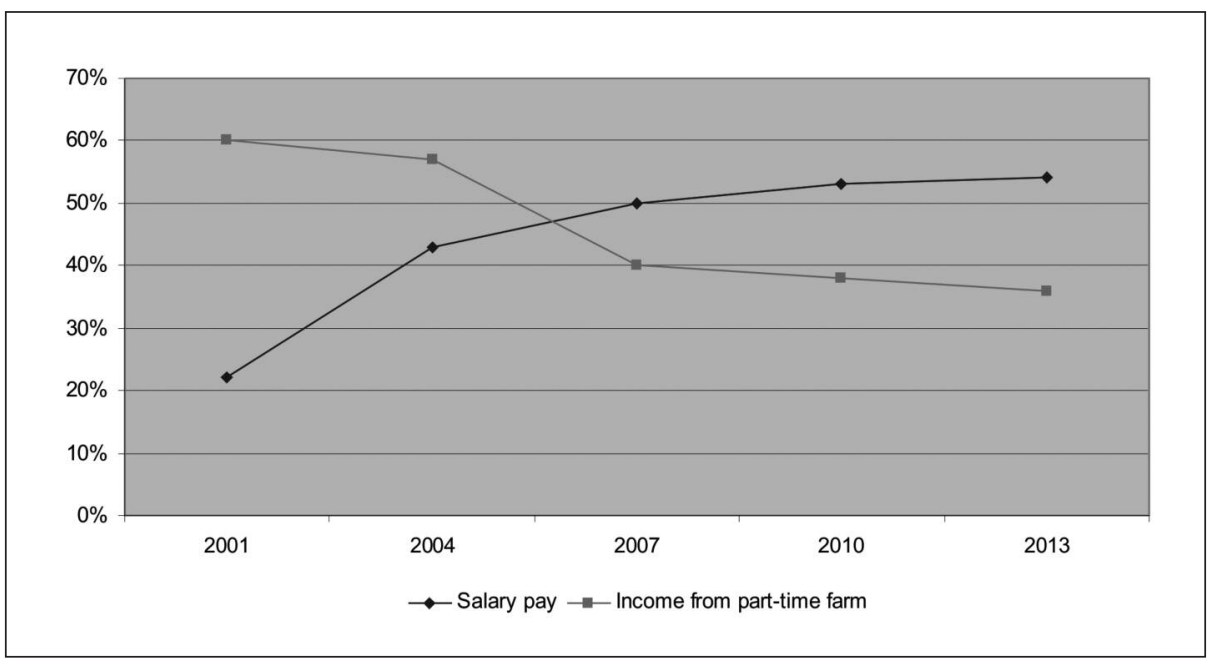

nomic growth of the 2000s, accompanied by the growth of social support the rural population, has led to a certain increase in the welfare of rural residents. The comparison of data of our surveys of various years show the appreciable positive tendencies of the point in question, but we need to explore further, how it is connected with the growth of a standard of well-being of rural population (Table 1).

Table 1. Incomes of the population

\begin{tabular}{|l|c|c|c|c|c|}
\hline Category & $\begin{array}{l}\text { Data } \\
2001\end{array}$ & $\begin{array}{c}\text { Data } \\
2004\end{array}$ & $\begin{array}{l}\text { Data } \\
2007\end{array}$ & $\begin{array}{c}\text { Data } \\
2011\end{array}$ & $\begin{array}{c}\text { Data } \\
2013\end{array}$ \\
\hline Abject poverty (less than 1/2 PM) & $67 \%$ & $52 \%$ & $58 \%$ & $47 \%$ & $22 \%$ \\
\hline Poverty (from 1/2 to 1 PM) & $27 \%$ & $36 \%$ & $37 \%$ & $42 \%$ & $40 \%$ \\
\hline $\begin{array}{l}\text { More than 1 PM on a member of a } \\
\text { family }\end{array}$ & $4 \%$ & $10 \%$ & $5 \%$ & $9 \%$ & $29 \%$ \\
\hline 2 PM and it is more & $2 \%$ & $2 \%$ & $0 \%$ & $2 \%$ & $7 \%$ \\
\hline
\end{tabular}

Even more important are not reformed and newly created agricultural companies, economy of large structures of the agricultural-holding type vertically integ- 
rated with the city capital. The similar enterprises have been actively developing during the last few years, and they are in more advantageous position in comparison with kruphozes, when it is about the possibility of attraction of the external capital, investment resources and use of modern technologies of the management, allowing them to flexibly change strategies, tactics and activity forms.

Consequences of such reorganization of the structure of the agricultural sector are ambiguous. On the one hand, effectively functional enterprise with participation of external investments provides local population with workplaces and promotes the solution of the acute problems of reformed society - poverty and unemployment. On the other hand, economic subjects of new type break the fragile balance which has developed in social sphere of village. First, anxious with first of all efficiency questions, "investors" insist on closing unprofitable kinds of business and dismiss "superfluous" workers. This leads to a new wave of unemployment and a hopeless situation in many villages, since the unemployment of a new wave is irreversible. Secondly, representing qualitatively new in innovative-capitalist way, agricultural holdings cease to carry out a number of functions of informal support of rural society, within the limits of developed in 1990s symbiosis models, acting in this plan as an antipode of "kruphoze", closely connected with local rural communities. The rupture of the developed system of the steady social and economic communications providing reproduction of resources of the social and human capital of village can initiate the destruction of spontaneously generated mechanisms of adaptation of agricultural population.

The situation in the rural settlements connected with functioning of agricultural holdings is characterized by sharp decrease not only of livestock and labor activity of the population in PPTF (that is caused by reduction of forms of support), but also reduction of the material resources accessible to community. The measures of a new management of optimization of a logistical chain of the manufacture include the sale technique of "kruphozes" and different method is used. The dismissal of workers leads to pauperization of the population which have lost not only work, but also possibilities of conducting a part-time farm (due to the absence of necessary resources).

The complexities of formation of a new institutional order and formation of multi-structures of rural economy have led to the occurrence of some problem situations in the rural society. The problems marked by inhabitants of village as sharpest are in certain communication (they are complex) and reflect objective complexities of economic and socio-cultural order. In consciousness of inhabitants of village, the following problems connected with an economic situation of the population prevail: unemployment, poverty, a delay of a salary (Table 2). 
Olga V. Nechiporenko, Vsevolod V. Samsonov, Russian Countryside: Stages of Change...

Table 2. The social problems of agricultural population, $\%$

\begin{tabular}{|l|c|c|c|c|c|}
\hline Problems & $\begin{array}{c}\text { Given } \\
2001\end{array}$ & $\begin{array}{c}\text { Data } \\
2004\end{array}$ & $\begin{array}{c}\text { Data } \\
2007\end{array}$ & $\begin{array}{c}\text { Data } \\
2011\end{array}$ & $\begin{array}{c}\text { Data } \\
2013\end{array}$ \\
\hline Unemployment & 65 & 60 & 55 & 77 & 91 \\
\hline Salary delay & 68 & 34 & 2 & 21 & 19 \\
\hline $\begin{array}{l}\text { Poverty and poverty } \\
\text { distribution }\end{array}$ & 47 & 35 & 17 & 21 & 58 \\
\hline Drunkenness & 71 & 37 & 24 & 71 & 73 \\
\hline Criminality & 24 & 7 & 4 & 8 & 34 \\
\hline Low birth rate, high death rate & 39 & 10 & 4 & 13 & 46 \\
\hline
\end{tabular}

The special aggravation of these problems occur in the case of the termination of activity of a large agricultural productions of innovative type, in conditions of exhaustion of the resources of adaptation of rural communities. The increase of destructive tendencies and the reduction of adaptive potential of rural society involve negative changes in the system of rural moving that is fraught with narrowing of sphere of social control over the non-urban territories, blasting the food and geopolitical safety of the country.

Summing up, it is once again necessary to underline that during the reformation of the Russian village some stages of development appeared, according to which dominating strategy of adaptation of rural society changed. Judging by observable tendencies of development of village, it is possible to assert that social and economic mechanisms of stabilization and maintenance of social balance in the rural society, the adaptations based on passive strategy, in a certain measure have settled the resource and today do not correspond to calls of the changed social and economic environment.

\section{Impacts of the global challenges in the modern Russian countryside}

The analysis of dynamics of social processes in modern Russian countryside has allowed us to reveal a number of the indisputable facts testifying the beginning of a new stage of transformation of rural society, which is connected with the start of multi-forms in village economy. The most significant displays of this process is "updating" of institution structure and changes of social and economic practices of population. 
The passive mechanisms of adaptation are gradually forced out by the innovative forms, whose expression in sphere of individual social and economic orientations is installation of formal employment. In institutional sphere these processes are accompanied by the development of organizational-industrial structures of new type; accordingly, the change of dominating model of social interactions appears. The theoretical interpretation of results of monitoring allows us to assume the conditionality of these processes of laws of the global structural transformations. Our research of structural changes of rural social and economic space in framework of the globalist paradigm allows us to allocate three basic trends of modern processes of rural development.

The first trend is characterized by economic differentiation (market specialization of regions and territories in the frameworks of globalised economy, following by the crisis of traditional forms of agricultural economy). The polarization of social and economic space shown in division (segmentation) of social and economic space in clusters of innovative changes, form "archipelago" of structures and degraded territories of domination of traditional economic ways (model of "economic compression"), with a chronic unemployment.

The accruing asymmetry in the international competition and the global restructuring of the food market causes the process of differentiation and agricultural economy segmentation. Increasing differentiation appears as the organizational-industrial bases (institutional aspects of changes) of rural economy, together with a place of agricultural structures in economic system of a society. Non-uniformity of changes generates differentiation of the social and economic space presented by clusters of innovative development and territories of domination of traditional economic forms, transitive formations and reflects various levels (and trajectories) of diversifications of rural economy in the countries and the regions which are at various stages of process of transformation. So, 2000s in Russia bring a clear tendency of "secondary concentration" of agrarian and timber industry manufacture in the large vertically integrated structures, initiated and both operated from the cities and using modern production technologies of processing and logistics. There are new spatial configurations generated by raw zones of these vertical structures, which caused strong polarization and a fragmentation of space of the country. Together with innovative development of separate territories and modernization of manufactures, remain the extensive areas of depressive and archaic countryside characterized by chronic unemployment of the population (Nefedova, 2013). The tendency of segmentation in social and economic space is strengthened by its division into the centre (there is a concentration of agricultural manufacture, especially its innovative forms, within city agglomerations) and periphery. 
Results of comparative researches show the possibility of rural self-development of the peripheral communities leaning on their own resources, in the form of small-scale way of the part-time farms, which are carrying out important social functions - from full indemnification of absence of possibilities of official employment (in villages without the employer) to auxiliary functions of increase of level of incomes of inhabitants of village and maintenance with their foodstuff. However, it is necessary to understand that the similar variant of development is not the universal scenario as it demands exclusively successful coincidence of variety of factors (the presence of free land, manpower, commodity markets etc.). Also, since the social situation in the surveyed villages of various regions differs slightly (and as a whole can be estimated critically), it is necessary to recognize the erroneous of exclusive rate of self-development (with expense of increase of market scales of personal economy, their actual transformation in a version of market farms).

The second trend of changes concerns the influence of global structural transformations on modern processes of adaptation of rural households and a diversification of rural economy. The most widespread adaptation reaction is the new configuration of economic activity and sources of the incomes, characterized by change of a role of agrarian works and the increasing importance of economic activity outside of agrarian sector and transfers, including the private ones (connected with migration and seasonal work ("neo-othodnichestvo"), and the state ones (connected with concrete systems of social support) (Losch, White, 2011: 36). The diversification of economy is expressed in the appeal of rural territories, that is the ability to involve resources and to keep the human potential substantially dependant on possibility of rural territories to create the alternative sources of the income which are not connected with agriculture (Saraceno, 1995; Richardson, 2000). The scale of this phenomenon has been generated by the numerous research literature devoted to "rural non-farm economy". Growth of not agrarian economic activity and employment of the population out of the village, accompanied by counter processes of a suburbanization involve cardinal change of a rural way of life and transformation of cultural shape of countrymen. In developing countries the diversification of economic activity of households is caused by insufficient possibilities of official employment in agrarian sector, an overabundance of the agrarian population and low incomes of agrarian work poorly equipped in the technical plan. In the developed countries of Europe the diversification is caused by impossibility of the further expansion of agrarian manufacture (in connection with achievement in the mid-eighties technological limits of growth), and multifunctionality of rural territories - new relations between a city and village with significant advantage for village (Ploeg, Renting, Brunori, 2000). 
Results of researches of social adaptation of rural local communities in the conditions of multi-structure economy (2008-2013, the Saratov, Novosibirsk, Kemerovo regions) have revealed the prevalence of model of social adaptation of the agricultural population, which has developed in the conditions of geographical affinity to the urban centers that provide additional possibilities and alternative, non-agrarian employment of the population: along with a salary and pensions, incomes of realization of production of part-time farms, as an additional important source of income, such as rotation-work and "neo-othodnichestvo". National economy is characterized by low marketability and the key parameters are similar to structure and the sizes of suburban country sites - that means the "city expansion" (with summer cottage and road building) on the one side, while the area of agricultural grounds is constantly reduced on the other.

Development of rural non-agrarian sector occurs non-uniformly, in connection with a primary inequality of objective conditions (adaptation resources) of rural communities. In connection with differentiation of rural social space and presence of difficulties of adaptation of some rural settlements and households to this process - there are risks of occurrence of transformation deadlocks for the whole communities and regions (when there are have no effective alternatives of a diversification of sources of incomes and directions of economic activity).

Thus, the third global trend of change of rural territories could be recognized in the processes of spatial and social differentiation, that generate risks of occurrence of transformation deadlocks connected with a lack of possibilities of alternative activity, shortage of resources (material, financial, ground) and limitation of a labor market. It leads to occurrence of "losing communities" for which the high level of poverty and the formation of steady tendencies to exclusion of the population owing to local restrictions are characteristic; thus all objective factors cause their further negative social and demographic dynamics. In case the situation is characterized also by the limited possibilities of migration, position of such communities (local, regional or even national level) becomes almost desperate. The given tendency (formations of "transformation deadlocks") is shown and in development of the Russian countryside in which the increasing distribution gets the destructive type of adaptation when the whole communities become social derelicts. The liquidation of large-scale enterprises, forming a basis of social and economic life of communities and economy of personal part-time farms, frequently leads to catastrophic decrease in a standard of living of inhabitants of village, degradation and destruction of rural local communities (Nechiporenko, Samsonov, 2012). Unemployment even more often becomes not the individual characteristic, but a sign of "identification" of the rural settlements which have remained without the employer. As the trigger mechanism of full degradation of such settlements 
local migration in job searches of the most able-bodied inhabitants then in village remain or pensioners, or margins layers not capable of independent managing acts. In 1990s such type of adaptation was seldom met though its separate elements could be found until the present moment in the tendency of destruction of rural communities, which became more widespread phenomenon. Apathy, refusal of elementary standards of consumption, transition to a subsistence economy, reduction of requirements, increase of asocial behavior - those are the characteristic features of rural settlements where there is no employer. So, in separate regions of Siberia the share of rural settlements in which large-scale enterprises are completely liquidated, makes from $30 \%$ to $60 \%$ from total number of settlements. The most strongly pronounced form of destructive type of adaptation of rural communities is gradual destruction and village extinction.

The noticed similarity of the processes in modern Russian countryside and the tendencies of change of rural society on a global scale calls for the reference to world experience - in search of ways of overcoming of problem situations and optimization of the general orientation of rural development. The analysis of such experience shows that, in connection with differentiation of occurring changes, the policy of external regulative influences should vary, first, from methods of "re-distributive" approach (in crucial regions), toward the stimulation of the objective processes, preventing formation of "transformation deadlocks" (including processes of an economic diversification). Secondly, formation of programs of territorial development is impossible without the objective account of local and regional specificity of territories, their internal resources of growth and problem points - that causes increase of the importance of territorial communities as object of monitoring supervision and interdisciplinary researches. 


\section{REFERENCES}

Bogoljubov, S.A., Brinchuk, MM., Vedysheva, I.O. (2011) Agrarnoe pravo (Agrarian Law). Moscow: Prospekt.

Losch, B., White, E. (2011) Rural Transformation and Late Developing Countries in a Globalizing World: A Comparative Analysis of Rural Change. Washington, DC: World Bank.

Marhinin, V.V., Udalova, I.V. (2002) Tradicionnoe hozjajstvo narodov Severa i neftegazovyj kompleks (Traditional economy of the North and the oil-gas sector). Novosibirsk: Nauka.

Nechiporenko, O.V., Samsonov, V.V. (2012), Hozjajstvennye uklady rossijskogo sel'skogo sociuma: modeli i strategii razvitija (Russian economic structure of rural society: models and strategies), Vestnik RGNF, 4 (169): 50-61.

Nefedova, T.G. (2013) Desyat aktualnyih voprosov o selskoy Rossii: Otvetyi geografa (Ten topical issues of rural Russia: Answers geographer). Moscou: Lenand.

Paciorkovskij, V.V. (2003), Sel'skaja Rossija: 1991-2001 gg. (Rural Russia: 1991-2001). Moscow: Finansy i statistika.

Ploeg, J.D., Renting H., Brunori, G. (2000) Rural Development: from Practices and Policies towards Theory, Sociologia Ruralis, 4: 391-408.

Richardson, T. (2000), Discourses of rurality in EU spatial policy: The European spatial development perspective, Sociologia Ruralis, 40 (1): 53-71.

Saraceno, E. (1995) Recent trends in rural development and their conceptualization, Journal of Rural Studies, 10: 321-330.

Vagin, V.V. (1997), Russkij provincial'nyj gorod: kljuchevye jelementy zhizneustrojstva (Russian provincial town: the key elements of living arrangement), Mir Rossii, 4: 53-88.

VCIOM (2010). Monitoring obshhestvennogo mnenija, 4(98), ijul'-avgust 2010. URL: http://wciom.ru. 


\author{
Олга В. Нечипоренко \\ Всеволод В. Самсонов \\ Институт за филозофију и право Руске академије наука, \\ Сибирски огранак, \\ Новосибирск, Русија
}

\title{
РУРАЛНЕ ОБЛАСТИ У РУСИЈИ: НИВОИ ПРОМЕНА, ПРИЛАГОЪАВАЮЕ РЕФОРМАМА И НОВИ ГЛОБАЛНИ ИЗАЗОВИ
}

Сажетак: Овај рад говори о генерализаџији искуства трансформаџије руског села, повезано са међусобним односом економских и друштвених аспеката трансформације, као и са анализом садашње ситуаџије у развоју руралних подручја, обоје због посебних ефеката пост-сочијалистичког наслеђа и глобалних изазова натег времена. Наши налази су засновани на резултатима проучавања промена у стратегијама адаптаџије руралног становништва Русије, обављених од стране аутора овог рада јединственим техникама у Сибиру, Волшком региону и Алтају од 1994. до 2014. године.

Кључне речи: диверзификаичја, диференцијација, друштвена адаптација, глобализаџија, економске структуре, поларизација, рурално друштво, рурални развој. 